\title{
The Directive on Antitrust Damages Actions and the European Leniency Program
}

\author{
Carsten Kunkel*, Giovanni Figá-Talamanca, Martina Semmler
}

\section{Zusammenfassung}

Die Europäische Kronzeugenregelung ist eines der wichtigsten Instrumente des Europäischen Wettbewerbsrechts. Kartellmitgliedern werden Anreize geboten, damit sie illegale, für den Wettbewerb schädliche, geheime Absprachen gegenüber der Europäischen Kommission offenlegen. Ausschlaggebend für die Teilnahme am Kronzeugenprogramm ist für Kartelle unter anderem, ob ein in Aussicht stehender vollständiger oder teilweiser Erlass der Geldbuße das Risiko von zivilrechtlichen Schadensersatzansprüchen überwiegt. Seitens der Europäischen Kommission müssen Anreize zur Teilnahme am Kronzeugenprogramm, aber auch eine wirksame Rechtsdurchsetzung für Geschädigte implementiert werden. Mit der Kartellschadensersatzrichtlinie soll eine harmonisierte, effektive Durchsetzung von Schadensersatzansprüchen gewährleistet werden. Dieser Beitrag kommt zu dem Schluss, dass die Stärkung der Durchsetzung zivilrechtlicher Ansprüche nicht konsequent umgesetzt werden konnte, da eine gewisse Diskrepanz zwischen dem Schutzzweck der Richtlinie und der Erhaltung des Europäischen Kronzeugenprogramms besteht.

\section{Abstract}

The European Leniency Program constitutes an important part of the anti-cartel enforcement and thus of the protection of sound competition. By offering incentives to cartel members, illegal detrimental agreements can be detected and penalized in order to stop infringement of the internal market. Companies willing to participate in the European Leniency Program however have to evaluate whether the offered incentives, i.e. full or partial immunity from fines, outweighs the possible risk resulting from private enforcement. With the Directive on Antitrust Damages Actions, the harmonized, effective enforcement of antitrust damage claims shall be ensured. The possibility of private enforcement constitutes a major threat to leniency applicants. It is the European Commissions' task and challenge to design an anti-cartel enforcement providing sufficient incentives for whistleblowers, while concurrently strengthening individuals suffering from cartels. The results show the dilemma and contradiction between the protection of the individual by strengthening the private enforcement and the need for an appealing leniency program.

\section{Introduction}

Cartels are a major threat to the internal market since they break competition law. By their nature, cartels have a negative influence on the market because they limit the competition that normally regulates the market. As a result, companies participating in cartels limit the pressure for participants on the market to remain competitive. Cartel agreements cause even more damage to the economy if they are concluded on a multinational level. According to Article 101 TFEU, all agreements between undertakings, decisions by associations of undertakings and concerted practices which may affect trade between member states and which have as their object or effect the prevention, restriction or distortion of competition within the internal market are prohibited. All agreements or decisions between undertakings which are prohibited according to Article 101 I TFEU shall be automatically void (Article 101 II TFEU). To be more precise, all agreements and/or concerted practices which are concluded between two or more competitors, designed to coordinate their competitive behavior on the market and/or to influence the market, e.g. through illegal price-fixing or sharing of markets ${ }^{1}$, are prohibited. However, if the prerequisites of Article 101 III TFEU are fulfilled (i.e. either block exemption or decision in an individual case), the exemption rule is applicable, i.e. the provisions of Article 101 I TFEU will be declared inapplicable. In order to benefit from an exemption under Article 101 III TFEU the agreement between undertakings, the decision by association of undertakings or concerted practice has to contribute to the improvement of the production or distribution of goods or promotion of 
technical or economic progress, while allowing consumers a fair share of the resulting benefit. However, the agreement, decision or concerted practice may not impose restrictions which are not indispensable to the attainment of these objectives and also may not eliminate competition in respect of a substantial part of the goods in question (Ezrachi 2016). Cartels cannot be subsumed under Article 101 III TFEU since they constitute the most serious violation of the prohibition according to Article 101 TFEU. Irrespective of the legal consequence of invalidity of any agreement or decision prohibited under Article 101 I TFEU, further legal consequences have to be observed, i.e. from both the European Union and national legislation. Article 101 II TFEU does not include any stipulations on civil penalties (e.g. indemnities). At national level, several legal consequences may apply, such as claims for removal, injunctive relief or indemnity. However, in the absence of European Union law ${ }^{2}$, it is the common position of the $\mathrm{ECJ}^{3}$ that any individual can rely on a breach of Article 101 I TFEU in front of a national court and claim indemnity for any damage suffered due to the cartel infringement ${ }^{4}$. This has been practice for many years. In order to achieve far-reaching harmonization on the secondary law of the member states in this regard, the European Commission published a Green Paper in $2005^{5}$, followed by a White Paper in $2008^{6}$, which then resulted in the issue of Directive 2014/104/EU7. With this Directive on Antitrust Damages Actions, the European legislator set out coordinated rules governing actions for damages under national law for infringement of competition law of the member states and of the European Union, as of 26th November 2014. By their means, directives have to be transposed into the national laws of the member states according to Article 288 TFEU, since they are part of the secondary law of the European Union. The Directive thus only provides the minimum requirements to be transposed into national laws. The member states were obligated to transpose the Directive into respective national laws until 27th December 2016 (Article 21 I Directive). In Germany, the transposition of the Directive into national law has been fulfilled with the 9. GWB Novelle $^{8}$, which became effective on 9 th June 2017.

This article deals with the question whether the special stipulations included for leniency applicants are sufficient and also lenient enough towards cartelists considering cooperating voluntarily with the European Commission and/or national competent authorities by providing significant information on the existence of and their role within the cartel, independently of the other cartelists involved. Furthermore, it is weighed whether the aim to protect and strengthen leniency programs is at the detriment of the protection of the individual suffering damages of antitrust infringements, as the actual protective purpose of the Directive.

\section{Purposes of the Directive}

\section{The Dilemma of the Detection of Cartels}

Anti-cartel enforcement is crucial for the European Union to maintain sound competition in the internal market. As the responsible institution for competition in the European Union, the European Commission focusses on the detection of illegal detrimental agreements, the punishment of cartel members and the cessation of infringements of the internal market. As a matter of principle, the secrecy of the cartel itself is an inherent part of each cartel. Hence, the willingness of a cartel member to blow the whistle is indispensable for the detection of any and all cartels. However, companies will only take the risk to reveal a cartel if the associated incentives are appealing enough compared to the related risks. This sums up the dilemma of the detection of cartels. Whereas they are secret by their means, they can and will only be detected if a participating company decides the incentives are appealing enough to take the associated risks. Solution methods to this dilemma are leniency programs.

Leniency programs ${ }^{9}$ constitute an important part of anti-cartel enforcement. By offering incentives to cartel members, illegal detrimental agreements can be detected and penalized in order to stop the infringement of the internal market. Whereas on the one hand, the possibility of total or partial immunity from fines is appealing to cartel members, they also have to consider whether the incentives offered outweigh the possible risk of private enforcement after participation in the leniency program. Since decisions of the European Commission are binding for all national courts (Recital 2 Directive), the application for leniency equates to an admission of guilt, which can in turn also be the basis for private enforcement. As a consequence, plaintiffs in a civil suit can refer to the decision of the European Commission as proof for the infringement of competition law and claim for the damages caused to them by such an infringement (Recital 3 Directive). For the most part, the civil suit focusses on questions of causality and the amount of damages to be awarded (Rother 2017).

\footnotetext{
${ }^{2}$ Directive 2014/104/EU of the European Parliament and of the Council of 26 November 2014 on certain rules governing actions for damages under national law for infringements of the competition law provisions of the Member States and of the European Union, L 349/1, Recital 11.

${ }^{3}$ EC) 20.09.2001, C-453/99, 24; EC] 13.07.2006, C-295/04 to C-298/04, 59; ECJ 14.06.2011, C-360/09, 28; ECJ 06.11.2012, C-199/11, 41; ECJ 06.06.2013, C-536/11, 23; ECJ 05.06.2014, C-557/12, 23

${ }^{4}$ EC) 20.09.2001, C-453/99, 24.

${ }^{5}$ Green Paper of 19.12.2005 on damages actions for breach of the EC antitrust rules, COM(2005) 672.

${ }^{6}$ White Paper of 2 April 2008 on damages actions for breach of the EC antitrust rules, COM (2008) 165.

${ }^{7}$ Directive 2014/104/EU of the European Parliament and of the Council of 26 November 2014 on certain rules governing actions for damages under national law for infringements of the competition law provisions of the Member States and of the European Union, L 349/1, in the following "Directive".

${ }^{8}$ Neuntes Gesetz zur Änderung des Gesetzes gegen Wettbewerbsbeschränkungen, BGBI I p. 1416.

${ }^{9}$ Besides the European Leniency Program, which has been established by the European Union in 1996, several national leniency programs are also applicable such as the German Leniency Program. For a detailed overview see also the list of National Competition Authorities which operate a leniency program as of November 2012: http://ec.europa.eu/competition/ecn/leniency_programme_nca.pdf.
} 
Therefore, the decision to apply for leniency is also always associated with considering the risk for the leniency applicant to be solely liable for the damages caused by the whole cartel because the leniency applicant will, other than cartelists who are not willing to cooperate with the European Commission, hardly decide for an appeal procedure in case full immunity is granted (Bulst 2008). As a result, the leniency applicant has a higher risk of becoming the defendant of private enforcement. The leniency applicant thus risks being the sole cartelist to be held liable for the infringement of the whole cartel (Bulst 2008). It has to be noted that within the concept of joint liability, the leniency applicant could indeed subsequently claim damages from the other cartelists, but, considering that the risk of litigation and insolvency is always with the plaintiff, this constitutes yet another risk for the leniency applicant who decided to blow the whistle (Schröter \& van der Hout 2015). Another major fear among cartelists is that the information provided within the leniency application may be used as evidence for private enforcement proceedings. In conclusion, it is self-evident that these risks influence the willingness of a cartelist to file a leniency application.

\section{Strengthening of Private Enforcement}

The infringement of European antitrust law causes damage per se to the internal market. Cartels limit the competition which normally regulates the market. As a result, cartelists limit the pressure for participants on the market to remain competitive. Therefore, there is no longer the necessity to develop new products or to improve the quality of the products because the concerned companies can rely on their market share, which is secured by the cartel, to name only one example. For the consumer, illegal practices result in less competitiveness on the market, which in turn may result in artificial prices ${ }^{10}$. Individuals suffering damages resulting from such infringements are protected according to Article 101 and 102 TFEU since those regulations stipulate rights for the individual that have to be enforced by national courts (Recital 3 Directive). Regardless of this right that already existed under the primary law of the European Union, the minority of victims of infringements of competition law claims for damage compensation in civil suits (Schröter \& van der Hout 2015). Various reasons can be found for that. However, the main aspect discouraging individuals from claiming antitrust damage are the difficulties related to evidence. It therefore can be stated that the access to evidence for the infringement of competition law is of crucial importance for any individual claiming damages resulting from this infringement (Keßler 2015). Therefore, as a matter of fact, the subjective rights to private enforcement of antitrust damages have to be protected.

In conclusion, two things have to be considered simultaneously in the design of European Competition law. On the one hand, the incentives provided for cooperation with the European Commission within the scope of leniency need to be appealing enough to convince cartelists to blow the whistle. On the other hand, subjective rights under European law, such as awarding damages to the victims of infringements of competition law, have to be protected. Those aspects were also considered and finally determined during the development of the Directive. As a result, the Directive finally (after nine years and several attempts) implemented European primary law ${ }^{11}$ - namely, the principle that any individual who suffered damages due to an infringement of competition law can claim such damages within civil suits - into European secondary law. The influence of private enforce- ment on the effectiveness of leniency programs was already acknowledged with the Green Paper ${ }^{12}$ on antitrust damages actions, followed by the White Paper $^{13}$ and now has finally resulted in the Directive (Keßler 2015).

\section{Lenient Leniency?}

The European legislator pursued two objectives with the Directive: First, it shall be ensured that victims of antitrust infringements can claim their suffered damages effectively; second, the interrelation between private and public enforcement shall be optimized ${ }^{14}$.

The Directive focusses on removing procedural obstacles in private damage actions to ensure protection of all individuals concerned, e.g. by awarding compensation to individuals for suffered damages (Recital 3 Directive). It has been underlined that existing divergence of applicable national rules regarding the enforcement of competition law shall be set aside with the Directive in order to protect the effectiveness of European competition law (Recitals 6, 8-10 Directive).

The Directive clarifies that any victim of infringement can claim full compensation of the damages suffered, covering the actual loss (damnum emergens) as well as loss of profit (lucrum cessans), respectively plus interest from the point in time the damage occurred until compensation (Recital 12, Article 3 II Directive). However, the Directive also explicitly excludes the possibility of overcompensation (Article 3 III Directive) and insofar follows consequently the compensation principle, which is also a recognized principle in German law (Keßler 2015). That means the compensation awarded shall place the person who suffered the damage in the position in which the person would have been if no infringement of competition law would have happened. Thus the individual shall not receive any further compensation exceeding that amount.

\footnotetext{
${ }^{10}$ Commission Notice on Immunity from fines and reduction of fines in cartel cases, 2006/C 298/11, 1.

${ }^{11}$ In this regard European primary law means the jurisdiction of the European Court of Justice; See: ECJ 20.09.2001, C-453/99, 26 et seq.; ECJ 13.07.2006, C-295/04, 61.

${ }^{12}$ Green Paper of 19.12.2005 on damages actions for breach of the EC antitrust rules, $\operatorname{COM}(2005) 672$, section 2.7.

${ }^{13}$ White Paper of 2 April 2008 on damages actions for breach of the EC antitrust rules, COM (2008) 165.

${ }^{14}$ European Commission; http://ec.europa.eu/competition/antitrust/actionsdamages/evidence_en.html; Proposal for a DIRECTIVE OF THE EUROPEAN PARLIAMENT AND OF THE COUNCIL on certain rules governing actions for damages under national law for infringements of the competition law provisions of the Member States and of the European Union /* COM/2013/0404 final - 2013/0185 (COD), section 1.2.
} 
It is one of the greatest obstacles for any plaintiff in competition law proceedings to gain knowledge of evidence that is relevant to substantiate their claim. Only sufficient evidence will substantiate claims of the plaintiff. Therefore, another important aspect for antitrust damages actions is the evidence to prove the suffered damage. Since cartels are secret as a matter of principle, cartel proceedings are always influenced by an information asymmetry (Recital 15 Directive) at the expense of the plaintiff. In most cases, the victim of the infringement obtains knowledge of the infringement of competition law only after a decision of the European Commission and hence private enforcement is mostly subsequently in the form of so called "follow-on-action" (Keßler 2015). This fact has been acknowledged and thus transferred into two sections of the Directive. First, Article 9 Directive stipulates that a final decision of a national competition authority shall be irrefutably established for the purposes of action for damages claimed before their national courts. That means any individual can refer to such a decision as the basis for the claim of damages resulting from the infringement. Second, Articles 5-8 Directive extensively stipulate the details under which preconditions the disclosure of evidence can be requested by a plaintiff, which legal aspects have to be considered by the national courts, and who can be requested to disclose evidence in such proceedings. Summarizing, the Directive includes numerous stipulations designed to strengthen private enforcement to protect subjective rights of individuals harmed by an infringement of competition law.

However, irrespective of the main objective of the Directive to strengthen private enforcement, emphasis has also been placed on the importance of leniency programs and other settlement procedures (Recital 26 Directive). The Directive recognizes the importance of leniency for the detection of cartels and, therefore, special regulations shall apply to cartelists who blow the whistle "to ensure [the] undertakings' continued willingness to approach competition authorities voluntarily with leniency statements or settlement submissions" (Recit- al 26 Directive). Those stipulations somehow seem to contradict the rules designed to strengthen private enforcement. In particular, according to Article $6 \mathrm{VI}$ Directive, the national law of the member states shall ensure that both leniency statements and settlement submissions are excluded from disclosure in front of national courts for the purpose of actions for damages. That means that no leniency application or submission for settlement of a leniency applicant can be used as evidence in front of a national court. To understand the significance of this stipulation, one has also to consider the definition of the term "leniency statement". According to Article 1 No. 16 Directive, a leniency statement includes any and all oral or written knowledge of a cartel, which is voluntarily provided to a competition authority. However, the leniency statement shall not include any pre-existing information. In conclusion, if already known information is included in the leniency statement, the rule of exemption for disclosure of such information in court is not applicable. Consequently, such information could be used in proceedings relating to an action for damages according to European competition law. With this flexibility clause it shall be ensured that the exemption rule does not contradict with the rights of the victim of the infringement to claim compensation for damages (Recital 26 Directive). According to Article 7 Directive, evidence from the categories of leniency statements or settlement submissions shall be deemed to be inadmissible in actions for damages or otherwise be prohibited under national laws.

This exemption clause is an excellent illustration of the fine line the European legislator is facing. Whereas on the one hand, the individual shall be protected by strengthening the private enforcement, on the other hand leniency applicants are also considered with the implementation of specific stipulations that place immunity recipients (irrespective of whether they are receiving total or partial immunity) in a better position. By excluding leniency statements as a source of evidence in antitrust damage actions, the legislator clearly favors the pro- tection of the cartelist applying for leniency over the need of protection of the individual's rights. One the one hand it seems consistent to encourage the participation in leniency programs with the benefit of the legal certainty that information provided within the scope of leniency application cannot be used as evidence in private enforcement against the leniency applicant. However, it also has to be noted that the promotion of the leniency program is obviously privileged over the strengthening of procedural rules in private enforcement and, in this case, privileged over the support to gain evidence for proving suffered damages. It could even be conceivable for leniency applicants to consider including a maximum of information into their leniency application, knowing that the information provided with the leniency application cannot be used as evidence in civil suits. Even though this encourages the detection of cartels, this clearly contradicts the strengthening of private enforcement.

Furthermore, special regulations regarding the joint and several liability have been implemented for immunity recipients. This is a considerable concession to cartelists willing to cooperate with the European Commission or national competition authorities. In general, according to Article 11 I Directive, cartelists are jointly and severally liable for the damage caused. However, Article 11 IV Directive significantly defuses the concept of joint liability by stipulating that the national law of the member states shall ensure that an immunity recipient is only jointly and severally liable in two cases: first, to its direct or indirect purchasers or providers, and second to other injured parties only if full compensation cannot be obtained from the other cartelists involved in the same infringement (Article 11 IV Directive). That means the joint liability of an immunity recipient is restricted. The immunity recipient will only be held liable for damages caused to third parties if indemnity cannot be received from the other cartelists involved, e.g. because of bankruptcy or insolvency of the undertaking. This obviously puts immunity recipients in a better position than other cartelists and is another example for the preference for leniency appli- 
cants to the detriment of the damaged party (Keßler 2015). Nevertheless, as outlined, a cartelist will always outweigh the risks and rewards related to blowing the whistle on the existence and involvement in a cartel. Certainly, the stipulations of Article 11 IV Directive relieve immunity recipients from large parts of the joint liability. However, if the damage of victims of the infringement cannot be fully compensated by the other cartel members involved in the same infringement, the immunity recipient will also be held liable for such cases. That means in case members of the cartel become insolvent and thus the injured party cannot be fully compensated by that cartel member, the cartelist who received immunity from either the European Commission or other national competent authorities will nonetheless be held responsible for the damage compensation. It is, therefore, doubtful whether the possible reward, i.e. in this case full or partial immunity from fines, outweighs the risk of private enforcement for members of the cartel.

\section{Conclusion}

In summary, it can be said that the realization of the two targets of the Directive, i. e. on the one hand ensuring that victims of antitrust infringements can claim suffered damages effectively by strengthening the private enforcement while on the other hand simultaneously optimizing the interrelation between private and public enforcement, was a major challenge for the European legislator. As demonstrated it is obvious that the implementation of specific stipulations for immunity recipients in order to provide incentives for cartelists considering cooperation with competent authorities goes to the detriment of the protection of the individual suffering damages of infringement of competition law by cartelists. In conclusion, the objective to strengthen private enforcement with specific stipulations (e.g. relief in questions of evidence) could not be pursued consequently since rules of exemption for the empowerment of leniency have also been implemented in the Directive. Therefore, the realization of the objectives into the Directive is not entirely convincing. One can conclude that the European legislator did not fully succeed in implementing secondary law that does justice to both immunity recipients and victims of their infringement. The extent to which the Directive will positively impact the private enforcement of antitrust damages actions in a conclusive way in light of the restrictive stipulations related to immunity recipients remains to be seen.

\section{REFERENCES}

Bulst FW (2008) Of Arms and Armour. The European

Commission's White Paper on Damages Actions for Breach of EC Antitrust Law. Bucerius Law Journal(2):81-95

Ezrachi A (2016) EU competition law. An analytical guide to the leading cases, 5th edn. Hart Publishing, Oxford, Portland, Oregon. ISBN: 978-1-5099-0983-4

Keßler J (2015) Die europäische Richtlinie über Schadensersatz im Wettbewerbsrecht - Cui bono? Verwaltung und Recht(3):83-92

Rother C (2017) Kartellschadensersatz nach der 9. GWBNovelle. NZKart Neue Zeitschrift für Kartellrecht(1):1-2

Schröter H, van der Hout R (2015) AEUV Artikel 101. In: Groeben H von der, Schwarze J, Hatje A (eds) Europäisches Unionsrecht, 7 th edn. Nomos, Baden-Baden, ISBN: 978-3-8329-6019-3

\section{AUTHORS}

Prof. Dr. iur. Carsten Kunkel

Technical University of Applied Sciences Wildau

Prof. Dr. Giovanni Figá-Talamanca

Martina Semmler, LL.M., PhD Candidate

University of Rome Tor Vergata

E-Mail for correspondence:

carsten.kunkel@th-wildau.de

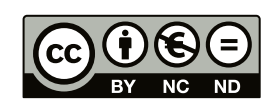

